УДК 782.1

17.00.00 Искусствоведение

\section{КОНЦЕРТ ДЛЯ ФОРТЕПИАНО С ОРКЕСТРОМ «КРАСОТА ВЕСНЫ» ДУ МИНСИНЯ: ОБРАЗНЫЙ СТРОЙ, ОСНОВНЫЕ СТИЛЕВЫЕ ЧЕРТЫ}

\section{Го Хаo}

аспирант кафедры музыкального воспитания и образования института музыки, театра и хореографии galkax@mail.ru

Федеральное государственное бюджетное образовательное учреждение высшего образования «Российский государственный педагогический университет им. А. И. Гериена», институт музыки, театра и хореографии; Санкт-Петербург, Россия

Статья посвящена истории создания фортепианного китайского концерта - «Красота весны» Ду Минсиня. На основе биографии композитора, реконструированной автором статьи по материалам взятого им интервью и другим источникам, воссоздается история появления Концерта. Дается краткая характеристика содержания и теоретический анализ основных выразительных средств и композиции всех трех частей. Установлено, что первая часть написана в форме сонатного Allegro с зеркальной репризой и виртуозной масштабной каденцией в ней, вторая часть - сложная трехчастная форма с эпизодом и финал - блестящая рондосоната. В заключении подчеркивается, что Ду Минсинь создал национальное по содержанию и интонации произведение на основе европейских классических канонов. Национальное воплощается, прежде всего, через мировосприятие, интонацию, ритмический рисунок. Среди большого комплекса выводов особо отмечается первостепенная роль традиций С. Рахманинова. Именно в его фортепианных концертах выразительные возможности восточной музыки, прежде всего ладоинтонационные, воплощены с уникальным художественным совершенством. В Концерте Ду Минсиня достигнуто классическое равновесие между соотношением партий солиста и оркестра. Фактура партии пианиста виртуозна, богата лирическими мелодиями, полноценно используется парный состав оркестра. «Красота весны» - концерт-соревнование равных творческих величин

КлючевЫе слова: ЕВРОПЕЙСКИЙ ЖАНР, КЛАССИЧЕСКИЙ ИНСТРУМЕНТАЛЬНЫЙ КОНЦЕРТ, СИМФОНИЧЕСКИЙ ОРКЕСТР, СОНАТНАЯ ФОРМА, ТРЕХЧАСТНАЯ ФОРМА, РОНДОСОНАТА, НАЦИОНАЛЬНЫЙ ЭЛЕМЕНТ
UDC 782.1

Art criticism

\section{PIANO CONCERTO "THE ELEGANCE OF SPRING" BY DU MINGXIN: FIGURATIVE SYSTEM, MAIN STYLE LINES}

\section{Guo Hao}

graduate student at the Department of Musical Education of Institute of Music, Theatre and Choreography galkax@mail.ru

State federative educational institution of higher education «Herzen State Pedagogical University of Russia», Institute of Music, Theatre and Choreography; St. Petersburg, Russian Federation

The article is devoted to history of creation of the piano Chinese concert - "The elegance of spring" by Du Mingxin. On the basis of the biography of the composer reconstructed by the author of article on materials interviewed by him and to other sources, the history of emergence of the Concert is recreated. The short characteristic of contents and the theoretical analysis of the main means of expression and composition of all three parts is given. It is established that the first part is written in the form of sonata Allegro with a mirror reprise and a masterly large-scale cadence in it, the second part - an irregular three-part shape with an episode and the final - shining the rondeau sonata. In the conclusion, it is emphasized that Du Mingxin has created the work, national on contents and intonation, on the basis of the European classical canons. National it is embodied first of all through attitude, intonation, the rhythmic drawing. Among a big complex of conclusions, the paramount role of traditions of S. Rachmaninov is especially noted. In his piano concerts, expressive opportunities of east music, first of all mode and intonation, are embodied with unique art perfection. In Du Mingxin's Concert classical balance between a ratio of parties of the soloist and orchestra is reached. The invoice of party of the pianist is masterly, rich with lyrical melodies, the pair structure of orchestra is fully used. "The elegance of spring" - a concert competition of equal creative sizes

Keywords: EUROPEAN GENRE, CLASSICAL INSTRUMENTAL CONCERT, SYMPHONIC ORCHESTRA, SONATA FORM, THREE-PART FORM, RONDEAU-SONATA, NATIONAL ELEMENT

\title{
Doi: 10.21515/1990-4665-132-013
}


«Красота весны» Ду Минсиня - крупнейшее произведение китайской музыки в жанре концерта для фортепиано с оркестром ${ }^{1}$. В китайской культуре, принадлежащей к одной из древнейших в мире, освоение европейских классических музыкальных жанров началось только на исходе XIX столетия. В XX веке Китай, как известно, отказался от политики изоляции и начал освоение достижений европейской цивилизации. Музыкальное искусство не было исключением в этом процессе. Появляются китайские романсы, кантаты, сольные и камерно-ансамблевые сочинения для европейских инструментов, опера европейского типа ${ }^{2}$, симфонические композиции и т. д.

Позднее всех стал развиваться жанр инструментального концерта, в том числе и фортепианного. Первый китайский концерт для фортепиано с оркестром - «Река Хуанхэ» Инь Чэнцзуна и творческой группы - Чу Ванхуа, Лю Чжуана, Шэн Лихуна, Ши Шучэна и Сюй Фэйсина был закончен в декабре 1969 года $^{3}$, то есть, только около шестидесяти лет назад, что исторически срок не большой. В 1970-80-е годы в Китае появляются другие произведения в этом жанре: «Интернационал» Чу Ванхуа и Чэнь Пэйсюня (1973), «Горный лес» Лю Дуньнаня (1979), «Божий дух» Чжао Сиошиня (1985) и др.

Это все замечательные, самобытные произведения, в которых композиционно-выразительные достижения европейского концерта соединяются с национальным музыкальным материалом и содержанием. Однако на сегодняшний день о них мало что написано. На русском языке можно со-

\footnotetext{
${ }^{1}$ В диссертации Ван Ин «Претворение национальных традиций в фортепианной музыке китайских композиторов XX-XXI веков» название концерта переводится как «Весенние пейзажи» [3]. На интернетфорумах можно встретить переводы «Дух весны» и т. д. Ранее автор настоящей статьи трактовал название как «Весеннее цветение». Сегодня мы пришли к выводу, что наиболее соответствует оригинальному смыслу «Красота весны». В английском переводе в первом издании партитуры значится «The elegance of spring» (Пекин: Pioples's music publishing house, 2011. 101 р.). По этому изданию нами приводятся в дальнейшем нотные примеры.

${ }^{2}$ Напомним, что в Китае многие столетия существовали разновидности сугубо китайской национальной оперы, так называемой традиционной.

${ }^{3}$ Подробно о концерте «Река Хуанхэ» см. в работах автора настоящей статьи $[6,7,8]$.
} 
слаться только на работы автора данной статьи $[5,6,7,8,9]$. В частности в одном небольшом фрагменте говорится о концерте «Красота весны» [9]. Не широк выбор и в китайской литературе: тезисы выступления на конференции Ли Цинь [10]; упоминание о фортепианных концертах китайских композиторов также можно встретить в общем контексте при характеристике симфонических произведений, созданных в Поднебесной за последние 50 лет [4], или в диссертации Цюй Ва, посвященной творчеству Чу Ванхуа [14]. При этом нельзя не отметить, что китайские фортепианные концерты весьма широко задействованы в исполнительской практике (безусловно, китайских пианистов). Рецензии на выступления пианистов, например, Инь Чэнцзуна или Ланг Ланга, в сущности, и являются основным публичным упоминанием об этих произведениях (не считая известного сайта Бэйту [1]).

Цель настоящей статьи - раскрыть содержательные и стилистические особенности концерта «Красота весны» Ду Минсиня, показать это произведение как достижение китайской музыки конца XX века.

Автор концерта Ду Минсинь (19 августа 1928 г. р.) - известный, старейший в КНР композитор. Однако в России о нем мало знают. Поэтому прежде чем перейти к характеристике его концерта «Красота весны», следует хотя бы кратко осветить его жизненный путь ${ }^{4}$. Ду Миньсинь родился в городе Циянцзян провинции Хубэй. У мальчика с детских лет проявились яркие музыкальные способности. Но в 1937 году в Шанхае разразилась война, и отец Ду Миньсиня ушел на фронт, чтобы бороться против жестоких японских захватчиков. В битве он погиб.

\footnotetext{
${ }^{4}$ Все биографические сведения о Ду Минсине основаны на материалах беседы с профессором Лю Циньтау из педагогического университета г. Аньян (КНР), у которого обучался автор статьи и играл детские пьесы Ду Менсиня с фольклорным тематизмом. Беседа состоялась в 2002 году в г. Синся провинции Хэнань (КНР). Ныне Лю Циньтау - профессор Вильнюсской консерватории им. Ю. Таллат-Кялпши (Литовская республика). Отдельные детали биографии Ду Минсиня взяты из интернет-сайтов, статьи «Китая музыка» из Музыкально-энциклопедического словаря [2].
} 
Осиротевшая семья переехала в провинцию Сицуан. Точно выяснить причины переезда пока не удалось, но важно одно, что мальчику очень захотелось учиться. Мама его в этом поддерживала, и переезд в Сицуан способствовал учебе: там была музыкальная школа. В начале 1939 года Национальный комитет по образованию постановил открыть в городе Цунцинь (провинции Сицуан) под руководством замечательного музыканта, композитора Тао Синьзжа музыкальную школу «Юцэй» для обучения талантливых детей.

Тао Синьзж вместе с коллегами отобрал наиболее одаренных ребят, среди которых оказался и Ду Минсинь. В школе работал известный композитор Хе Людинь, у которого Минсинь обучался фортепиано. По музыкально-теоретическим предметам и композиции его наставником был Жинь Гуан.

К 1941 году относится создание первой, дошедшей до нас песни начинающего композитора. В 1949 году Минсинь отправился в Пекин для работы в ансамбле народной песни и танца. Там молодой композитор сразу обратил на себя внимание, и в 1954 государство направило его для совершенствования в Московскую государственную консерваторию им. П. И. Чайковского. Он обучался в классе известного композитора Михаила Ивановича Чулаки. Пребывание в России, глубокое проникновение в русскую классическую и советскую музыку оказало влияние на творческие предпочтения Ду Минсиня и на питавший его композиторское воображение комплекс традиций. Это достаточно убедительно подтвердится в концерте «Красота весны» (о чем будет сказано далее). В Москве Ду Минсинь работал в различных жанрах. Он написал фортепианное трио, сольные фортепианные пьесы, для ансамбля трех пианистов и другие инструментальные произведения.

\footnotetext{
${ }^{5}$ Список произведений Ду Миньсиня помещен в сети интернет на сайте Бэйту (百度) [1]. 
Когда в 1958 году Ду Минсинь вернулся на Родину, то в этом же году была открыта Пекинская (Центральная) консерватория, и его пригласили преподавать композицию и фортепиано.

В трагическую эпоху Культурной революции Ду Минсинь один из наиболее авторитетных композиторов КНР. Его деятельность очень многогранна: он - член Союза композиторов Китая, исполнительный директор Ассоциации китайских музыкантов. Но главное - очень интенсивное творчество. Начиная с 1960-х годов, на пике мастерства он обращается к балету, осваивает крупные симфонические жанры, пишет музыку к драматическим спектаклям и кино. Но славу ему принесли балеты «Рыба-красавица» (1959) и революционный «Красный отряд женщин-бойцов» (1964), написанные в соавторстве с У Цзучаном. В 1969 году он возглавил группу по созданию балета «Красный отряд женщин-бойцов», ставшего одним из наиболее знаменитых его произведений.

В 1976 году Ду Минсинь возвратился к преподавательской деятельности в Центральной консерватории в качестве профессора композиции и декана.

Ду Минсинь - автор Симфонии «Великая китайская стена», трех фортепианных концертов, двух концертов для скрипки с оркестром, трех симфонических поэм и увертюр, пяти поэм для камерного оркестра, множества камерно-инструментальных ансамблей и сольных произведений, хоров, песен и романсов соло и для дуэта. Немало он работал для ансамбля народной музыки.

Концерту «Красота весны» предшествовала целая серия фортепианных и симфонических произведений. Процесс этот, на наш взгляд, начинается с 1977 года, когда был создан эмоционально-приподнятый, «искрящийся» «Молодежный вальс» - развернутая по форме блестящая пьеса для фортепиано. В данном контексте также следует отметить симфоническую картину «Родное южное море», симфоническую фантазию «Розелла». По 
образному строю, виртуозному владению фортепианной и симфонической фактурой эти произведения следует считать предтечами фортепианного концерта. Непосредственно с ним связан и Концерт для скрипки с оркестром (тоже первый). Следовательно, концерт для фортепиано с оркестром «Красота весны» Ду Минсинь пишет в расцвете творчества, когда он приобрел опыт работы в разных жанрах и сложился его широкий культурный кругозор. Необходимо заметить, что композитор пробует силы сразу в двух инструментальных концертах - для скрипки и для фортепиано.

«Красота весны» создавалась в 1986-1987 году в период реформ и открытости - время высокого творческого подъема, исключительно благотворное для работы. Именно веяния этого времени стимулировали вдохновение композитора, формирование новых образных замыслов и инновационных методов их воплощения. Ду Минсинь создает произведения разные по содержанию, значительные по концепциям. Важнейшей задачей становится включение национального элемента в жанры и формы западноевропейской и русской музыки. Эти идеи окончательно воплотились в Концерте № 1 для фортепиано с оркестром. Его стиль обладает ярко выраженным национальным элементом, в чем важнейшую роль играют фольклорные ритмы.

В 1994 году концерт для фортепиано с оркестром «Красота весны» был отмечен первой премией на VIII Всекитайском композиторском конкурсе.

Названием «Красота весны» композитор обозначил образ, воссозданный в этом произведении, стимулировавший его рождение эмоциональный мир. Эта музыка вызывала у Ду Минсиня ассоциации с весной, расцветом природы, периодом обновления. Следует заметить, что параллели с природой являются характерной чертой китайской музыки, в том числе и фортепианной $[9,11]$. 
Концерт состоит из трех непрограммных частей - это типичная европейская конструкция сонатно-симфонического цикла с указанием темпов. Первая часть - Largo. Allegro con spirito - написана в сонатной форме со вступлением, активной многоступенчатой разработкой, интонационно богатой, ярко развивающейся каденцией, в чем не последнюю роль играет темповая динамика. Вторая часть - Largo в сложной трехчастной форме. И искрометный финал - Allegro - рондо-соната.

Вступление первой части (Largo) отличается задушевностью и теплотой. На нежном аккордовом фоне скрипок в высоких октавах гобой выводит пасторальную мелодию (пример 1). Это важный для становления части образ. Элементы его мелодического рельефа впоследствии преобразуются в других темах. Вступление основано на двух повторяющихся фразах гобоя (они отличаются только трактовкой метрической опоры). В тишине, как отголосок, гобою отвечает соло фагота. Все три фразы как бы демонстрируют зарождение ключевой интонации, основанной на квартоквинтовом опевании (fis-h, gis-cis). 
1 І часть Вступление

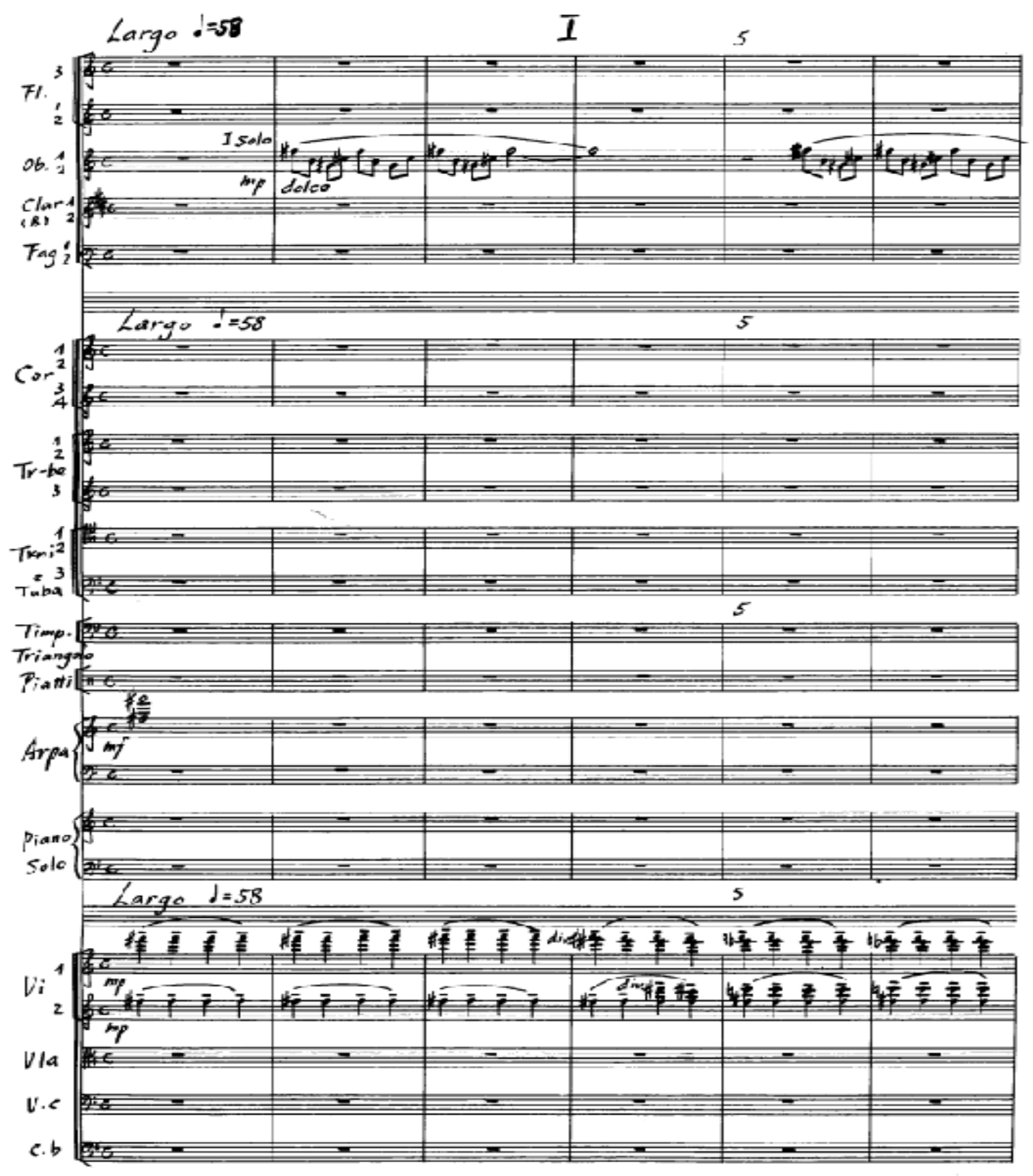

Завершается вступление ажурными пассажами фортепиано в tempo rubato. Партия солирующего инструмента как бы демонстрирует не только семантику прелюдирования в его изначальном значении, но и семантику одной из природных стихий - легкого ветерка. Так в совокупности живописуется картина зарождения весеннего дня, едва заметного начала буйного обновления всего живого. 
Основная тема главной партии ${ }^{6}$ (Allegro con spirito) - волевая, не лишенная императивности, ярко выраженного энергичного народного характера (пример 2). Этот характер создается приоритетом в ее облике ритмического рисунка со специфическим синкопированным ритмом.

Мелодический контур опирается на кварто-квинтовые интонации с постоянным «отталкиванием» от доминанты $g$, «раскачкой» по интервалам кварты, квинты, сексты и, наконец, «завоевание» октавы. Расширение диапазона темы ассоциируется с накоплением мощных сил. Именно эта идея интервальной «раскачки» была заложена во вступительной мелодии гобоя (см. пример 1). Ясно очерченные мелодические фразы чередуются с виртуозными наигрышами. Энергичный характер усиливает и графически четкое октавное изложение партии солиста, контрастирующее с живописным романтическим вступлением своей quasi реалистичностью, подчеркнутой мускульностью.

Уже при экспонировании тема активно варьируется, ее октавы фактурно укрупняются, а наигрыши из отдельных фигур на основе гармонических последований трансформируются в поток виртуозно-прихотливых пассажных гаммообразных узоров (с т. 41). Они подводят к новому каденционному построению - своего рода связующей теме перед вступлением П.П.

Побочная партия предельно контрастна по всем выразительным параметрам: темпу - Largetto, тональности - уходом в далекий от C-dur'a Desdur, метро-ритмом с переменным размером $-4 / 4 \rightarrow 3 / 4 \rightarrow 4 / 4 \rightarrow 3 / 4$ и т. д. (после регулярной ритмики Г.П.). Контрастна и жанровая семантика с ее «убаюкивающими» фактурно-ритмическими формулами колыбельной (сначала у рояля, затем по всей оркестровой партитуре), всплесками арпеджио, направляющими воспринимающее сознание к семантике водной стихии.

\footnotetext{
${ }^{6}$ В дальнейшем мы пользуемся общепринятыми для сонатной формы аббревиатурами: Г.П. (главная партия), П.П. - побочная партия, 3.Т. - заключительная тема и т. д.
} 

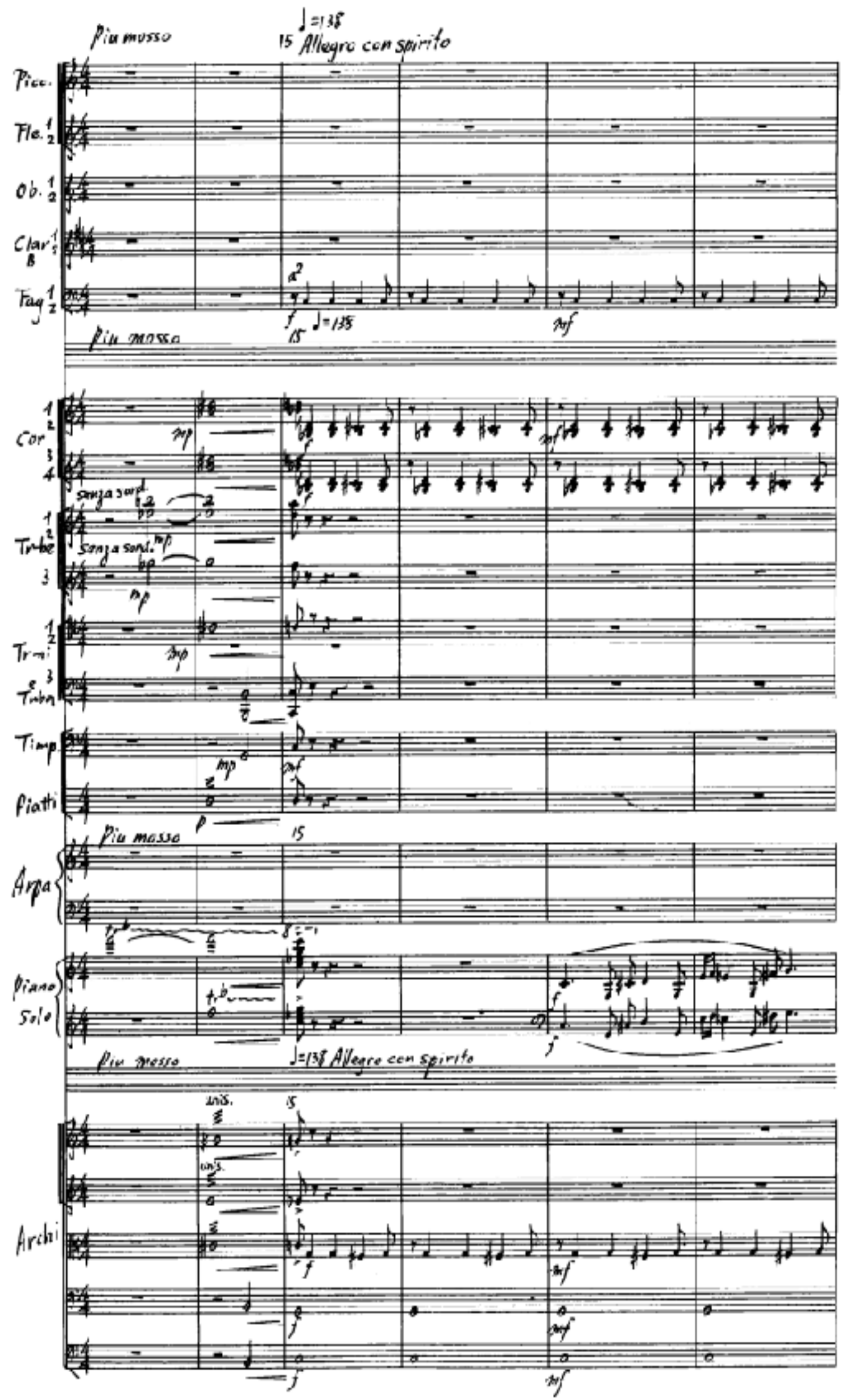


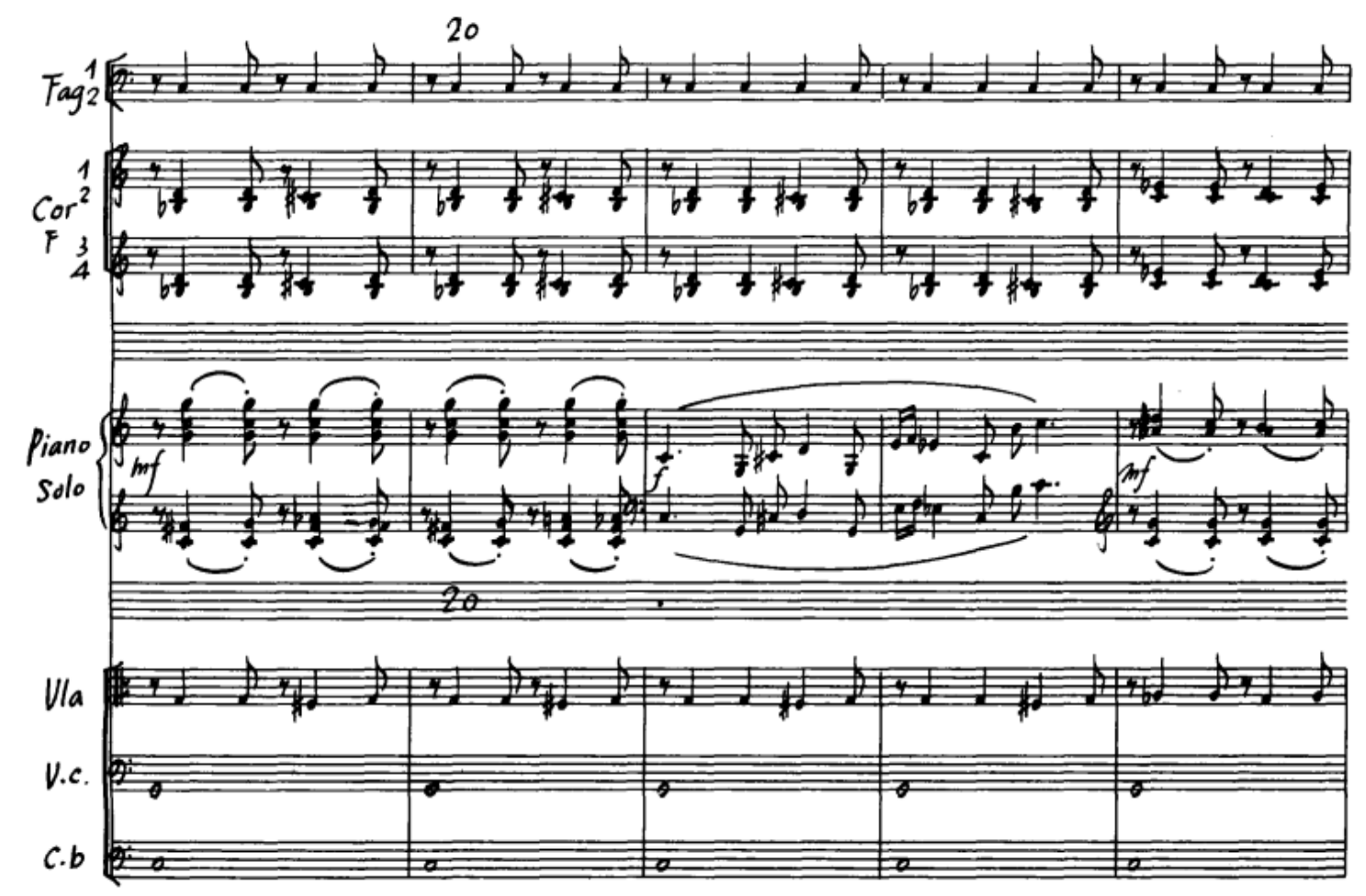

Если попытаться определить жанровую природу П.П. - это вечерняя песня на лоне природы. В ее изложении используется имитационный метод: завершающая восходящая фраза попеременно пропевается кларнетом, фортепиано, флейтой, гобоем. Их переклички на фоне педального аккомпанемента создают образ прихотливых сумеречных видений. В партии скрипок переинтонируются исходные мотивы из вступления. Эта попевка становится абрисом завершающей фразы П.П., которая звучит в разных группах оркестра и, в конечно счете, образует лаконичную 3.Т. При повторном проведении у фортепиано она фактурно укрупняется (т. 88-94) и переходит в разработку. По существу именно кульминация П.П. трансформируется в короткую заключительную тему.

Разработка начинается мощными позывными меди - соло валторн (не случайно их 4, несмотря на парный состав оркестра), в котором в победном Des-dur «обыгрывается» Г.П. с ее чередованием чистой и уменьшенной квинт. Разработка включает три раздела, границами которых помимо тематизма, смены исполнительских групп являются и темповые обо- 
значения: I - a tетро (Largetto), II - poco accelerando $\rightarrow$ III - Allegro. Если I раздел сугубо оркестральный, то со II раздела (с т. 102) вступает соло фортепиано вплоть до конца разработки. Здесь начинается росо accelerando, в движении которого секвенционно, по восходящим тональностям - Des - Es - G развивается новая виртуозная тема, подводящая к III кульминационному разделу. На фоне волнообразных фигураций в фортепианной партии проходит величественная эпическая Г.П. в увеличении (пример 3). В ней уже нет и следа исходной танцевальности, она обретает черты величественного гимна.

3

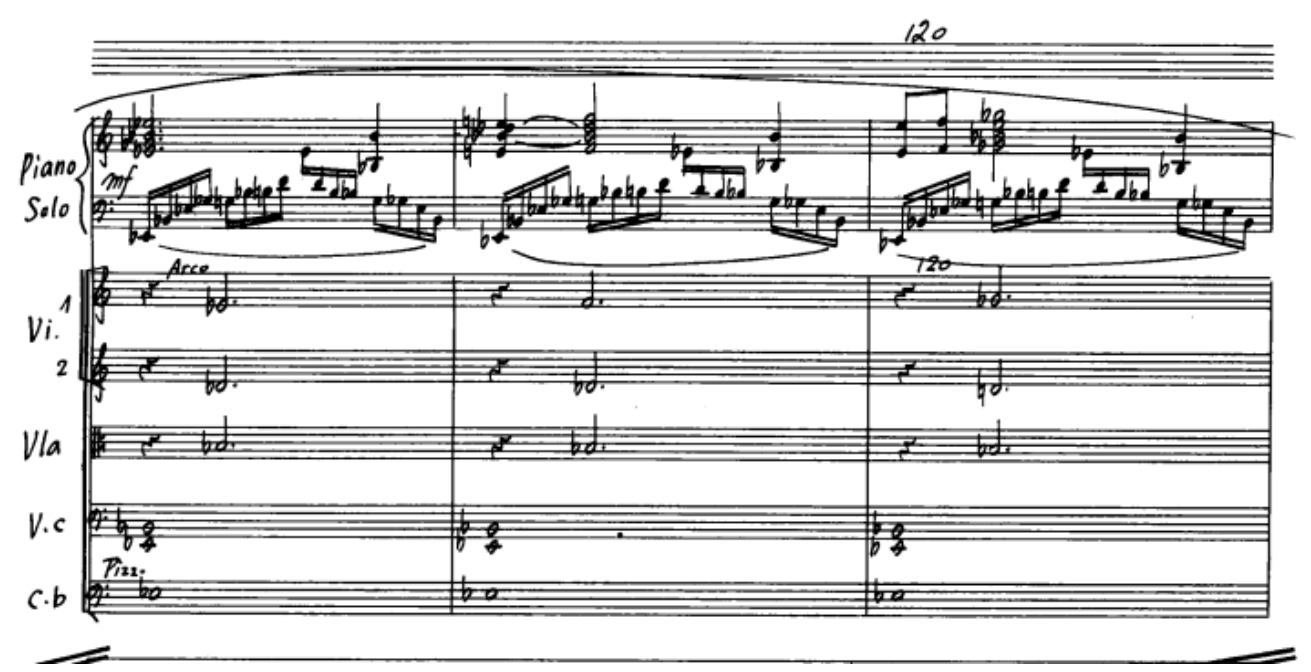

Затем (с т. 132) начинается показ виртуозных возможностей рояля различных пассажных фигураций через всю клавиатуру, в том числе движение терциями в правой руке, переходящее в аккорды и мощные октавы обеих рук с двойным темповым увеличением (авторская ремарка в т. 161: половинная длительность = четверти). После короткого ritenuto в темпе Adagio (т. 180) вступает П.П. Она появляется в ином, нежели в экспозиции, - восторженно победном звучании tutti (тональность d-moll).

Таким образом, первая часть представляет собой сонатную форму с зеркальной репризой. Причем, в отличие от классического канона каденция не предваряет репризу, а разъединяет П.П. и Г.П. В динамизированном облике репризы продолжается развитие тематизма. 
Вслед за оркестром П.П. звучит у солиста, подводя к масштабной, типичной для классического концерта каденции. В ее ведущей мелодии преобразуется структура мелодического рельефа вступления. Квартовые и квинтовые интонации попеременно звучат в параллельном движении в обеих руках (пример 4).

4

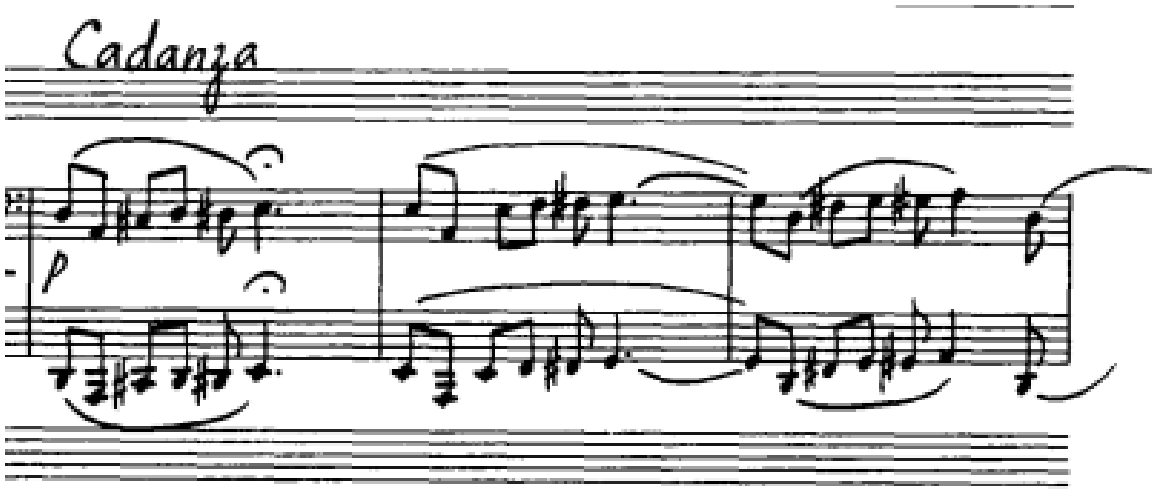

В дальнейшем партии обеих рук, благодаря принципу инверсии, как бы вступают в единоборство. Создается образ противоречия, который затем, на основе трансформации инверсионных фактурных формул в параллельное движение аккордами в перерождается в образ преодоления.

Резким контрастом звучит вторая часть - лирическое Largo, вдохновенный ноктюрн. В его теме особенно впечатляют кварто-квинтовые удвоения мотивных окончаний, несущие изобразительно-семантическую функцию: как будто далеко в долине эхом разносится китайская песня (пример $6)$.

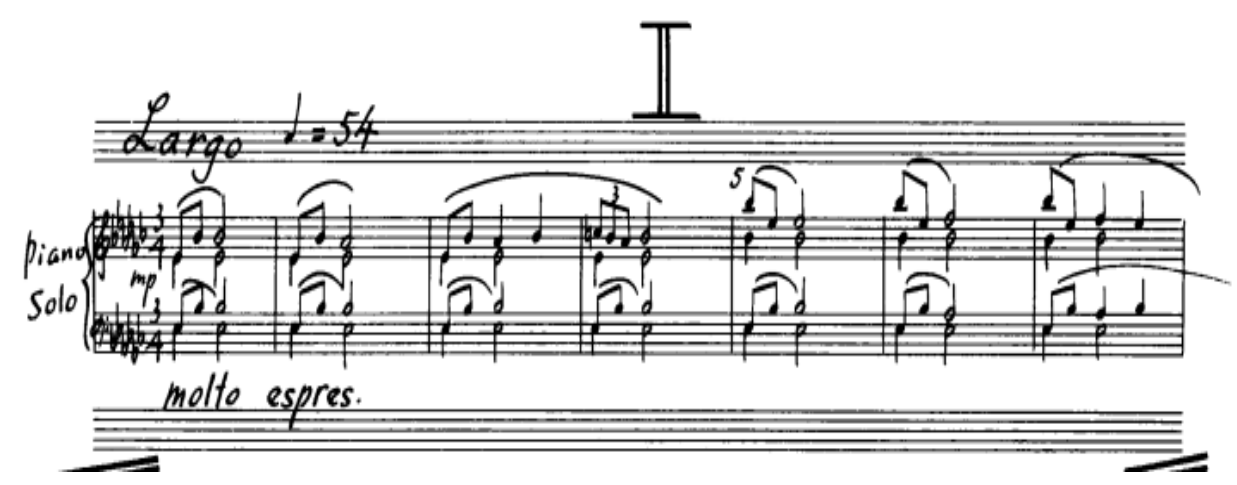


Фактура в партиях обеих руках очень прозрачна, основана либо на дублировке, либо на мелодическом противодвижении.

Начало части - песня солирующего фортепиано, которую с 9 такта подхватывают кларнет и фагот на фоне ажурного аккомпанемента фортепиано (ломаные трезвучия в высоком регистре с педальной тонической квинтой - Es-dur в басу и колористическим аккордом в середине клавиатуры).

Первый раздел представляет собой простую трехчастную форму с развивающей серединой на основе солирующей флейты (с. т. 23). В целом Largo написано в сложной трехчастной форме.

В репризе мелодию вновь ведет фортепиано на фоне педальных звучностей медных и низких деревянных духовых. Они сочетаются с виртуозными фигурами на основе ломаных интервалов и острых созвучий staccato, как бы напоминающих о танцевальном жанре.

Искрометный, активно-танцевальный финал в форме рондо-сонаты буквально пронизан токкатными виртуозными фигурами в фортепианной партии, лежащими в основе рефрена (пример 7). Рефрен и оба эпизода не контрастируют друг другу. В финале практически нет мелодического материала (за исключением небольших восходящих фраз в басу), и тематизм построен на общих формах движения. Исходя из семантического анализа, можно предположить, что это образ скачки, столь характерный для восточных сюжетов.

Оптимистичному характеру финала соответствует светлый C-dur. B структуре фигуры его рефрена важную роль играют тоны $G, C, A, D$, образующие остинатное чередование нисходящей квинты и восходящей кварты. Благодаря этим оборотам возникают ассоциации со звучанием китайского народного музыкального щипкового инструмента nunbl (пример 7).

С такта 211 начинается заключительная мощная каденция. Фортепианное соло длится до 260 такта, демонстрируя доминирование рахмани- 
новского и глазуновского концертного пианизма. Именно его фресковый облик «широкого мазка» (если обратиться к аналогиям с живописью) утверждает приподнято-эмоциональный, ораторский тон Концерта.

7

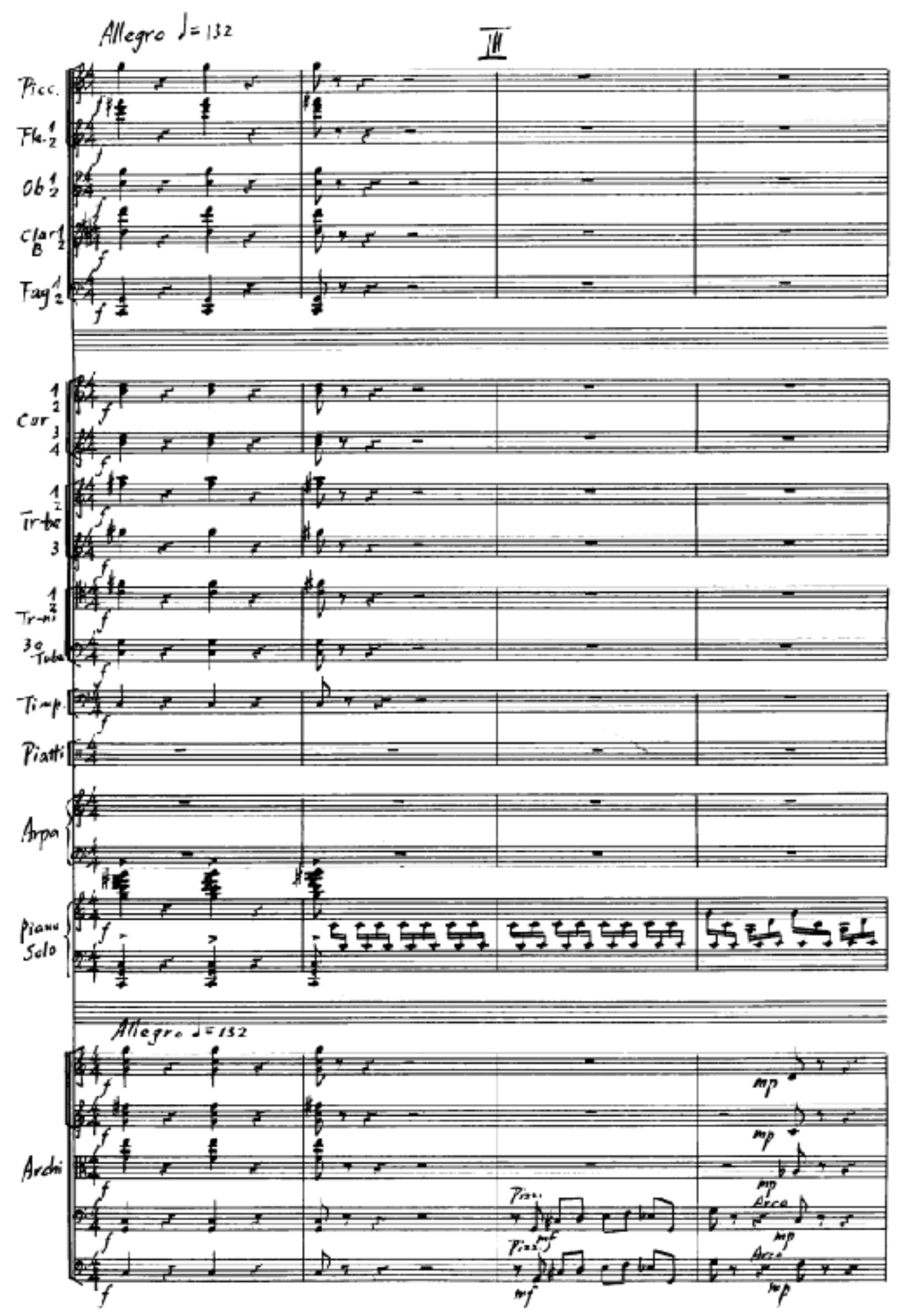


Итак, «Красота весны» относится к числу исключительно виртуозных фортепианных концертов конца XX века. В нем нет авангардных приемов ни в плане звукоорганизации, ни трактовки выразительных средств, ни композиционных решений. Это произведение целиком и полностью продолжает традиции классического концерта. Причем наиболее животворными являются традиции русских классических концертов XX века, прежде всего С. В. Рахманинова и А. К. Глазунова. Поэтому полноту эмоционального высказывания сообщает сочинению красота и приоритетность мелодического мышления в сочетании с фактурной изобретательностью. Масштабность фактурного рисунка и мощь звучания, обилие фортепианных соло, особенно в виде виртуозных каденций, придают произведению ярко выраженные черты концерта-соревнования.

Наиболее приоритетными являются традиции С. В. Рахманинова, что обусловлено рядом причин. Прежде всего, фортепианные концерты великого русского композитора - единственные в истории данного жанра, которые отличаются ярким и художественно совершенным воплощением выразительных возможностей восточной музыки. Об этом свидетельствуют как слушательская интерпретация, так и аналитическая практика (о восточном элементе в творчестве Рахманинова неоднократно писали исследователи $\left.^{7}\right)$. Немаловажен и тот факт, что Ду Минсинь учился в Московской консерватории им. П. И. Чайковского у М. И. Чулаки и всю жизнь испытывал любовь и пиетет перед русской музыкальной культурой.

Нельзя не отметить и связь с рапсодийными традициями Ф. Листа, прежде всего его «Испанской рапсодией». Прежде всего, с принципом монотематизма, который проходит через всю листовскую композицию, где уже первые грандиозно-величественные аккорды темы вступления предвещают основную тему «Испанской рапсодии» - Folia. Также важна роль

\footnotetext{
${ }^{7}$ Прежде всего следует отметить диссертацию и монографию Д. А. Рахимовой «Ориентализм в творчестве С. В. Рахманинова» $[12,13]$.
} 
«пассажных» каденций; динамизированных вариационных принципов, обусловленных постепенным фактурным «обрастанием», изложением тематического материала на основе «игры» параллельным движением октавами и их противодвижением и др.

Вместе с тем, Концерт Ду Минсиня является современным и новаторским. Новизну ему придает прежде всего национальная китайская интонация, которая до того мало воплощалась в жанре фортепианного концерта (причем только китайскими авторами). Национальная основа проникает и через звукоподражание китайским музыкальным инструментам.

Если исходить из программного заголовка произведения - «Красота весны», то его концепция основывается на показе разных сторон образа. В первой части - это образ постоянного развития, стремление к безостановочному обновлению. Не случайно эта часть завершается активным развитием Г.П., благодаря которому, несмотря на «устойчивые» заключительные аккорды, ее форма становится как бы разомкнутой, устремленной далее - к Largo. И действительно, весна наиболее динамичное время года (что в совершенстве воплощено Рахманиновым).

Вторая часть - поэтичный ноктюрн, весенняя песня поэтичного томления, предожидания обновления и счастья. Она вызывает аналогии со второй частью («И ночь, и любовь») из фортепианной Сюиты № 1 для двух фортепиано Рахманинова.

Финальная третья часть - радость всеобщего ликования от весны. В ней воссоздается та энергия, которой наполняется в это время года все жиBoe.

В воплощении концепции не последнюю роль играет темповая трансформация, тем более, если учесть, что каждая темповая ремарка (кроме ritenuto и accelerando) отмечена метрономическим указанием. Ocoбенно показательна в этом плане первая часть: Largo $\rightarrow$ ritenuto $\rightarrow$ Allegro con spirito $\rightarrow$ Largetto $\rightarrow$ piu accelerando $\rightarrow$ Allegro $\rightarrow$ ritenuto $\rightarrow$ Adagio и т. 
д. К тому же следует добавить, что такты 211-260 включают мощную каденцию, которая apriori предполагает tempo rubato с приоритетом accelerando. В репризе вступление Г.П. явно должно быть в быстром темпе (хотя он не указан композитором), который остается до конца части.

Национальное начало воплощается, прежде всего, через интонацию, ритмический рисунок, в частности синкопированный в Г.П. первой части (см. пример 2), через темпо-ритм - как регулярный, так и с переменным тактовым размером (на чем построена образная антитеза главной и побочной партий). О национальном элементе свидетельствуют семантика звучания народных китайских инструментов, приемы варьирования. Национальное предстает через мироощущение и приоритет образов природы.

В заключение подчеркнем, что в концерте «Красота весны» достигнуто равновесие между соотношением партий солиста и оркестра. Пианисту есть, что поиграть: фактура его партии виртуозна, богата лирическим мелодизмом. Парный оркестр при этом используется полноценно. В партитуре действительно представлен концерт-соревнование, но соревнование равноценных творческих величин.

\section{Литература:}

1. Бэйту (百度) ${ }^{8}$ : Онлайн энциклопедия [китайской музыки]. - URL: https://baike.baidu.com/item/杜鸣心/4581843?fr=aladdin

2. Васильченко, Е. В. Китая музыка // Музыкальный энциклопедический словарь / гл. ред. Г. В. Келдыш - М.: Сов. энциклопедия, 1991. - С. 250-251.

3. Ван, Ин Претворение национальных традиций в фортепианной музыке китайских композиторов XX-XXI веков: Автореф. дис. ... канд. иск: 17.00.02 / Ин Ван. СПб., 2009. -23 с.

4. Ван, Люйхэй 50 лет китайской фортепианной музыки. Обзор и перспективы / Люйхэй Ван. - Пекин: Народная музыка, 1999. - 120 с.

5. Го, Хао История создания и образный строй концерта для фортепиано с оркестром «Горный лес» Лю Дуньнаня // // Музыкальная культура глазами молодых ученых: Сборник научных трудов - СПб.: Астерион, 2015. - Вып. 10. - С 106-109.

6. Го, Хао Концерт для фортепиано с оркестром «Река Хуанхэ»: аналитический экскурс // Музыкальная культура глазами молодых ученых: Сборник научных трудов.СПб.: Астерион, 2016. - Вып. 11. - С. 95-102.

7. Го, Хао Концерты для фортепиано с оркестром в творчестве китайских композиторов. Основные типологические черты // Современные проблемы науки и образова-

\footnotetext{
${ }^{8}$ Перевод всех китайских источников принадлежит автору статьи - Го Хао.
} 
ния. - 2015. - № 2 - URL: http://www.science-education.ru/131-23925 (дата обращения: 03.12.2015).

8. Го, Хао Образы природы как творческий импульс в становлении китайского фортепианного концерта // Музыкальная культура в теоретическом и прикладном измерении: Сборник научных статей.- Кемерово: КемГУКИ 2016. - Вып. 3. - С. 90- 94.

9. Го, Хао Роль программного элемента в китайском фортепианном концерте // Музыкальная культура глазами молодых ученых: Сборник научных трудов. - СПб.: Астерион, 2017. - Вып. 12. - С. 174 - 178.

10. Ли, Цинь «Красота весны» // Квалификации: Журнал. Конференция: резюме. 2015. - Вып. 9.

11. Природа в китайской культуре и музыке [материалы рубрики] // Китайская музыка. - 2002. - № 3.

12. Рахимова, Д. А. Ориентализм в творчестве С. В. Рахманинова: Автореф. дис. ... канд. искусств.: 17.00.02. - СПб., 2011. - 19 с.

13. Рахимова, Д. А. Ориентализм в творчестве С. В. Рахманинова [Монография]. Волгоград, 2013. - 206 с.

14. Цюй, Ва. Фортепианное творчество Чу Ванхуа в контексте китайской музыки XX века: Дис. ... канд. искусств. - Ростов н/Д., 2015. - 233 с.

\section{References}

1. Beytu (百度): Onlayn entsiklopediya [kitayskoy muzyki]. - URL: https://baike.baidu.com/item/???/4581843?fr=aladdin

2. Vasilchenko, E. V. Kitaya muzyka // Muzykalnyy entsiklopedicheskiy slovar / gl. red. G. V. Keldysh - M.: Sov. entsiklopediya. 1991. - S. 250-251.

3. Van, In Pretvoreniye natsionalnykh traditsiy $\mathrm{v}$ fortepiannoy muzyke kitayskikh kompozitorov XX-XXI vekov: Avtoref. dis. ... kand. isk: 17.00.02 / In Van. - SPb.. 2009. $23 \mathrm{~s}$.

4. Van, Lyuykhey 50 let kitayskoy fortepiannoy muzyki. Obzor i perspektivy / Lyuykhey Van. - Pekin: Narodnaya muzyka. 1999. - 120 s.

5. Go, Khao Istoriya sozdaniya i obraznyy stroy kontserta dlya fortepiano s orkestrom «Gornyy les» Lyu Dunnanya // // Muzykalnaya kultura glazami molodykh uchenykh: Sbornik nauchnykh trudov - SPb.: Asterion. 2015. - Vyp. 10. - S 106-109.

6. Go, Khao Kontsert dlya fortepiano s orkestrom «Reka Khuankhe»: analiticheskiy eks-kurs // Muzykalnaya kultura glazami molodykh uchenykh: Sbornik nauchnykh tru-dov.SPb.: Asterion. 2016. - Vyp. 11. - S. 95-102.

7. Go, Khao Kontserty dlya fortepiano s orkestrom $\mathrm{v}$ tvorchestve kitayskikh kompozito-rov. Osnovnyye tipologicheskiye cherty // Sovremennyye problemy nauki i obrazova-niya. - 2015. - № 2 - URL: http://www.science-education.ru/131-23925 (data obrashche-niya: 03.12.2015).

8. Go, Khao Obrazy prirody kak tvorcheskiy impuls v stanovlenii kitayskogo fortepiannogo kontserta // Muzykalnaya kultura v teoreticheskom i prikladnom izme-renii: Sbornik nauchnykh statey.- Kemerovo: KemGUKI 2016. - Vyp. 3. - S. 90-94.

9. Go, Khao Rol programmnogo elementa $\mathrm{v}$ kitayskom fortepiannom kontserte // Muzy-kalnaya kultura glazami molodykh uchenykh: Sbornik nauchnykh trudov. - SPb.: Asterion. 2017. - Vyp. 12. - S. 174-178.

10. Li, Tsin «Krasota vesny»// Kvalifikatsii: Zhurnal. Konferentsiya: rezyume. - 2015. - Vyp. 9.

11. Priroda v kitayskoy kulture i muzyke [materialy rubriki] // Kitayskaya muzyka. 2002. - № 3. 
12. Rakhimova, D. A. Oriyentalizm v tvorchestve S. V. Rakhmaninova: Avtoref. dis. ... kand. iskusstv.: 17.00.02. - SPb.. 2011. - $19 \mathrm{~s}$.

13. Rakhimova, D. A. Oriyentalizm v tvorchestve S. V. Rakhmaninova [Monografiya]. - Volgograd. 2013. - $206 \mathrm{~s}$.

14. Tsyuy, Va. Fortepiannoye tvorchestvo Chu Vankhua v kontekste kitayskoy muzyki KhKh veka: Dis. ... kand. iskusstv. - Rostov n/D.. 2015. - 233 s. 